\title{
Detection of Abnormal Conditions Based on Analysis of Cyclic Movement in Scene Image
}

\author{
Yoshiki Terada Non-member (Gifu University) \\ Fumihiko Saitoh Member (Gifu University)
}

Keywords : automatic detection of abnormal conditions, periodicity, motion-image sequence

This paper proposes a general-purposed method for automatic detection of abnormal conditions in scene images using the periodicity of motion-images. FFT is a typical method for detecting wave cycle, but it isn't suited for speedy detection of the disorder. The proposed method realizes speedy detection of abnormal conditions.

Fig.1 shows the flowchart of the proposed method. Frames are divided into multiple blocks and these are processed on the time-series sequence. First, in order to detect some action in blocks, each block is converted into the binary sign that represents the block includes an action or not. In order to detect the cyclic pattern, the proposed method uses the voting of binary signs into the frequency vote tables. The entropies of the vote tables represent the strength of periodicity and the cycle synchronization. The disorder of a cyclic motion can be detected by monitoring the increase of the entropy. The abnormal point is represented by the intensity of the disorder. When the abnormal point exceeds a threshold, it is assumed that the abnormal condition occurs. The speedy detection of an abnormal condition is realized because the proposed method uses only 1 frame for its detection.

The motion-image sequences with $320 \times 240$ pixels size, 256 levels grayscale and 10 frames per second were used as the experimental images. The block size was set to $8 \times 8$ pixels.

Table 1 shows the results of the detection of the abnormal conditions using the proposed method and the conventional FFT. "False" and "Success" mean the maximum numbers of the blocks with the false detection and the successful detection in 1 second. The proposed method recorded the higher $R$, which means the higher reliability, for all images in comparison with the method by FFT.

Fig.2 shows the frames of the experimental scene images with the marks of the blocks with the abnormal condition. It is found that the marks were increased as soon as the moving toy train stopped.

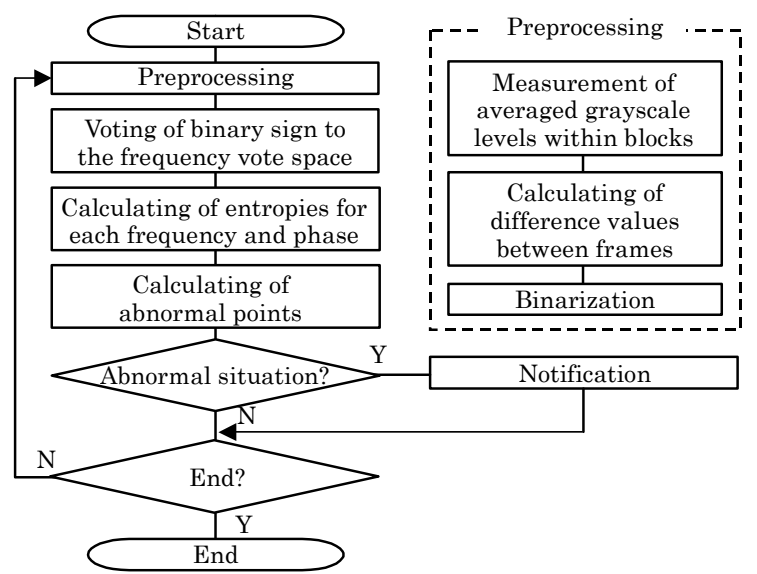

Fig. 1. Flowchart of the proposed method

Table 1. Comparison of proposed method with FFT

\begin{tabular}{l|c|c|c|c|c|c}
\hline \hline \multirow{2}{*}{ Image } & \multicolumn{3}{|c|}{ FFT } & \multicolumn{3}{c}{ Proposed method } \\
\cline { 2 - 8 } & False & Success & $R$ & False & Success & $R$ \\
\hline \hline (1)Train & 150 & 396 & 2.64 & 59 & 378 & 6.41 \\
\hline (2) Bird & 374 & 460 & 1.23 & 62 & 607 & 9.79 \\
\hline (3) Signal & 374 & 380 & 1.02 & 62 & 163 & 2.63 \\
\hline (4) Board & 70 & 710 & 10.14 & 15 & 434 & 28.93 \\
\hline (5)Books & 10 & 196 & 19.60 & 34 & 5757 & 169.33 \\
\hline
\end{tabular}
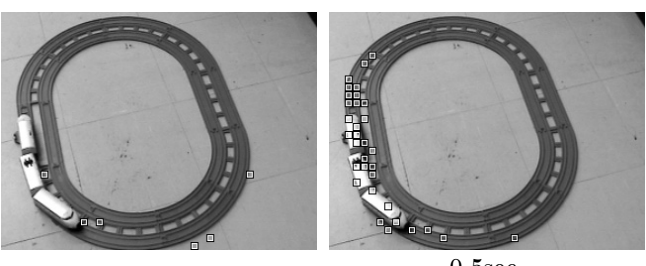

$0.5 \mathrm{sec}$

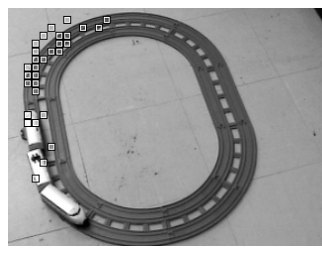

$1.0 \mathrm{sec}$

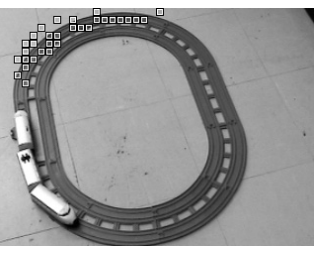

$1.5 \mathrm{sec}$

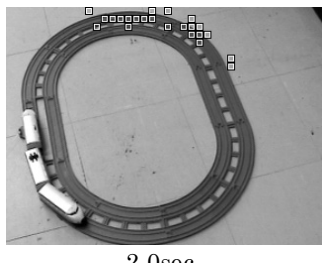

$2.0 \mathrm{sec}$

Fig. 2. Results of detection just after the abnormal situations occurred 


\title{
論 文 \\ 動画像の周期的動作解析に基づく異常状況検出 \\ 非会員 寺田 吉希* 正 員 斉藤 文彦* \\ Detection of Abnormal Conditions Based on Analysis of Cyclic Movement in Scene Image \\ Yoshiki Terada*, Non-member, Fumihiko Saitoh*, Member
}

\begin{abstract}
Automatic detection of abnormal conditions in scene images is an important research theme. This paper proposes a general-purposed method for automatic detection of abnormal conditions based on the analysis of periodicity of movements. In the proposed method, cyclic movements are detected by voting binarized averaged grayscale values into each frequency. The disorder of movements, which represents the occurrence of abnormal situation, can be recognized by monitoring the change of bias conditions in voting. The experimental results showed that the reliable detections for periodicity and the speedy detections of abnormal conditions were realized in the general situations.
\end{abstract}

キーワード : 自動的異常検出, 周期性, 動画像処理

Keywords : automatic detection of abnormal conditions, periodicity, motion-image sequence

\section{1. はじめに}

近年，画像処理技術の普及に伴い，自動監視システムや 監視支援システムの研究が多くの分野で進められている。 画像処理を利用した監視システムでは，従来のレーザ光に よるセンサなどを用いた手法(1)と比べて, 得られる情報量が 多く, また一般的に特殊な装置を必要とせずカメラのみを 設置するだけで監視が実現できると言う利点が存在する。

監視のためのシステムの一例としては, 工業用ロボット の異常動作検出(2) や, 人物の行動パターンに着目した非日 常状態の検出 ${ }^{(3)}$, 交通映像からの異常事象の検出 ${ }^{(4)}$, 赤外 線画像を利用した IC ボードの故障検出 ${ }^{(5)}$ ，あるいはネット ワークカメラを利用した遠隔監視のためのシステム(6)など, その分野は多岐に渡る。これらの従来研究では, ロボット の固有な動作特徴の利用 (2), あるいは人間の動作に対して Hidden Markov Model (HMM) を用いることにより，行動 パターンとして学習・認識を行う(3) など，一般的に対象物 体に依存する固有動作特性を用いることで, より精度の高 い異常監視を実現している。しかし，これらの手法では対 象物体固有の特徵量を利用するため, 工業用ロボットや人 物の動作といった特定の対象に対しては高い精度を実現し ているが，各種の分野に汎用的に利用することを目的とし た手法についてはほとんど研究されていないのが現状であ

\footnotetext{
* 岐阜大学工学部応用情報学科

T501-1193 岐阜県岐阜市柳戸 1-1

Department of Information Science,

Faculty of Engineering, Gifu University,

1-1 Yanagido Gifu-shi, Gifu 501-1193
}

る。

本論文は, 動画像の周期的動作に着目し, その周期性が 乱れた場合を異常状況と定義することにより, 各種の監視 対象について, 汎用的に異常状況の検出を行うことを目的 としている。規則的に動作する物体を対象とし, その物体 の動きに異常が発生した場合にそれを検出する。また同一 のアルゴリズムを用いて, 不審者の侵入など突発的な動作 の検出が可能であり, より汎用性の高い異常状況検出を実 現する。

規則的な周期性を検出する方法としては高速フーリエ変 換 ${ }^{7}$ (FFT) が一般的に知られている。FFT では, 画像の 濃度值等の入力波形を周波数空間に変換し, パワースペク トルのピーク位置から入力波形の周期を知ることができ, 例えば，FFT を利用して手振りの検出を行う方法が提案さ れている(8)。また，時間軸を移動しながら FFT を行う短時 間フーリエ変換によって, 周期の変化を検出することがで きるが，現時刻からある程度さかのぼった時刻までの区間 の入力データを用いて処理を行うため, 映像の取り込み区 間内に異常発生前のデータが残っている場合には誤認が発 生しやすいという問題が発生する。

本論文では，ブロック分割された動画像に対し，ブロッ クごとに各フレーム間の差分情報を 2 值で算出し, 出現頻 度の偏り（エントロピー）を周期ごとに求めることで, 各 周期における動作の周期性の強さを算出する方法を提案す る。周期性の情報を利用し, 最新フレームにおける周期性 の乱れを判断することで, 即時に異常状況の検出を行う。 実験を通し, 提案手法によって動作の周期性が正しく検出 

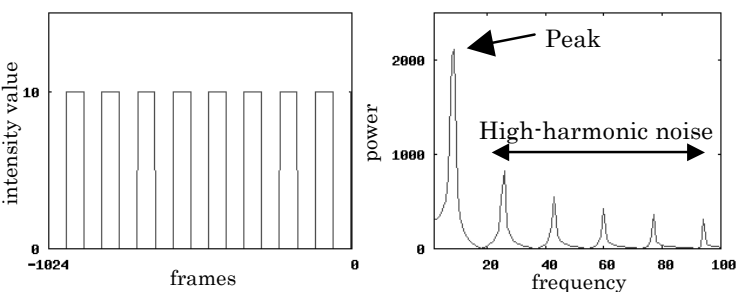

(a) Normal rectangular wave

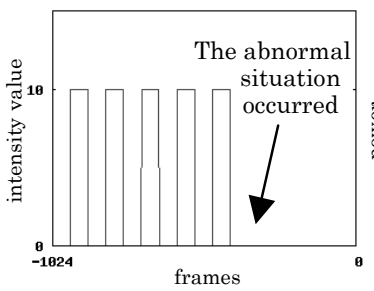

(c) Abnormal wave (b) Power spectrum of (a)

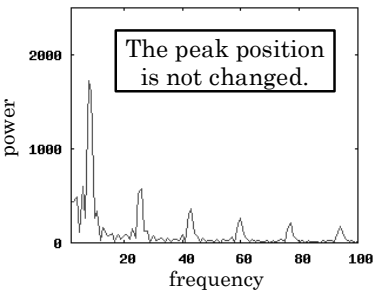

(d) Power spectrum of (c)
図 1 周期性の乱れた波形における $\mathrm{FFT}$ 結果

Fig. 1. Results on disordered cyclic wave by FFT

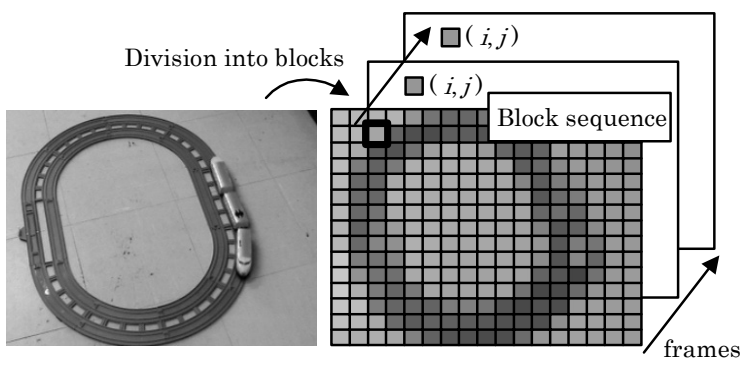

図 2 ブロック列の生成

Fig. 2. Generation of block sequences

され，正確な異常検出が実現できることを示す。

\section{FFT を利用した周期性と異常状況検出}

FFT は，信号の周波数成分を解析する際に用いられる手 法である。文献(8)の手法のように，低解像度化された濃淡 動画像の濃度值について, 時間軸方向に一次元の FFT を行 うことを考える。入力波形に対して FFT を行い，周波数空 間に変換した後, 出力されたパワースペクトルの最も強い 成分を含む周期を調べることで入力波形の周期を知ること ができる。しかし，手振りのように正弦波に近い入力信号 に対して処理を行う場合はうまく周期を求めることが可能 であるが，図1(a) に示すような正弦波以外の波形に対して FFT を行う場合，入力波形の周期の成分以外にも高調波等 の成分が含まれ，図 1(b) に示すようなノイズの多いパワー スペクトルが出力される。

また FFTでは，現時刻からある程度さかのぼった時刻ま での区間内の入力データを取り込んで処理を行う。そのた め, 図 1(c) に示すような異常発生直後における取り込み区 間内に異常発生前のデータが残っている場合，図 1(d) に示 すようにピーク位置が変化せず，異常検出を行うことがで

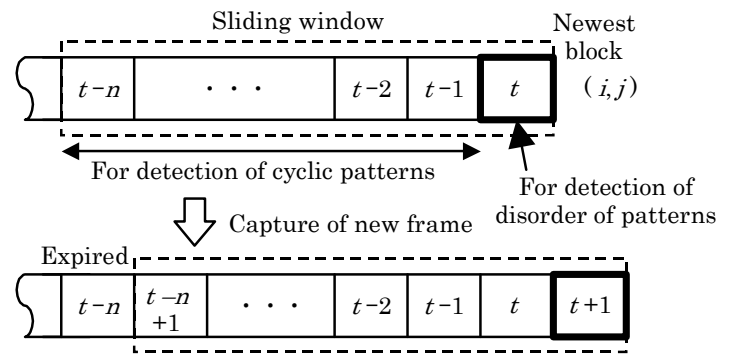

図 3 ブロック列におけるスライド空

Fig. 3. Sliding window on block sequence

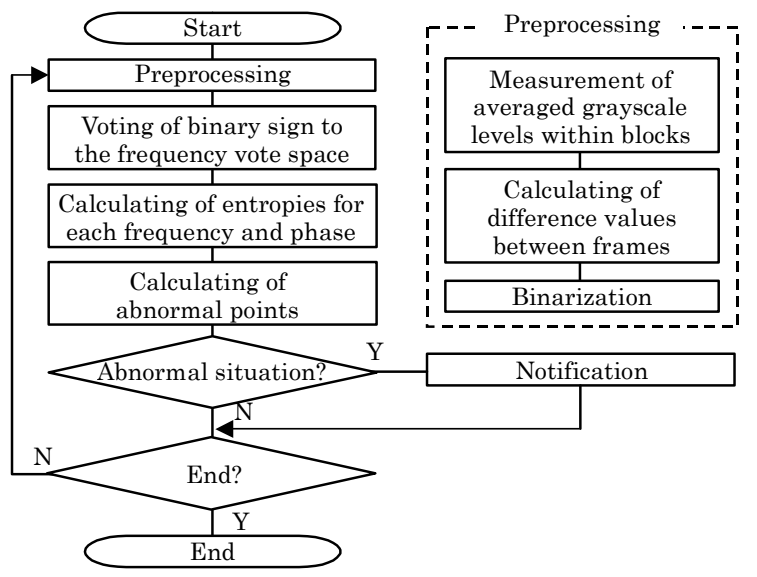

図 4 提案手法の流れ

Fig. 4. Flowchart of the proposed method

きないという問題が発生する。異常発生からある程度の時 間が経過し, 取り込み区間内に異常発生前のデータが残っ ていない状態ならば，ピーク位置の変化を利用し異常検出 を行うことができるが，異常発生から検出までのタイムラ グが発生する。データの取り込み区間を短く設定すること でタイムラグを短くすることはできるが，それでも即時性 を求められる用途では不十分といえる。

\section{3. 投票エントロピーを利用した異常状況検出}

前述のように, FFT を用いた手法では入力信号に対する ノイズや異常検出までのタイムラグが問題となる。この問 題を解決するために以下の方法を提案する。

〈3・1〉本手法の考え方 本手法では, 図 2 に示すよ うに画像をブロック単位に分割し，同一位置のブロックに 対して時間軸方向に注目したブロック列を作成する。ブロ ックの分割数を $N_{\text {block }}$ とするとブロック列の数も $N_{\text {block }}$ とな り, 各ブロック列に対しては独立して処理を行う。そのた め処理時間はブロックの分割数にほぼ比例する。

次に，周期性の検出を行うためのブロック，および異常 検出のためのブロックを設定する。図 3 に示すように, 周 期性の検出には, 最新フレームの直前から $n$ フレーム前ま でのブロックを使用し，異常検出には，最新フレームにお ける 1 ブロックを使用する。また，新しいフレームが入力 された場合, 処理対象のフレームの範囲を表すスライド空 


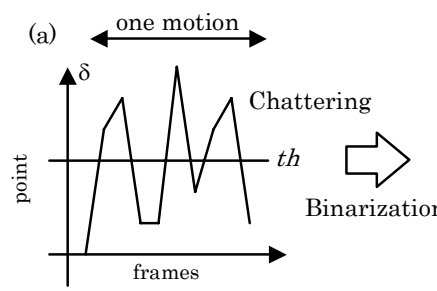

(b)

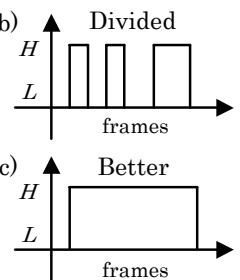

図 5 テクスチャを持つ物体移動時の 2 值化

Fig. 5. Binarization for moving object with texture

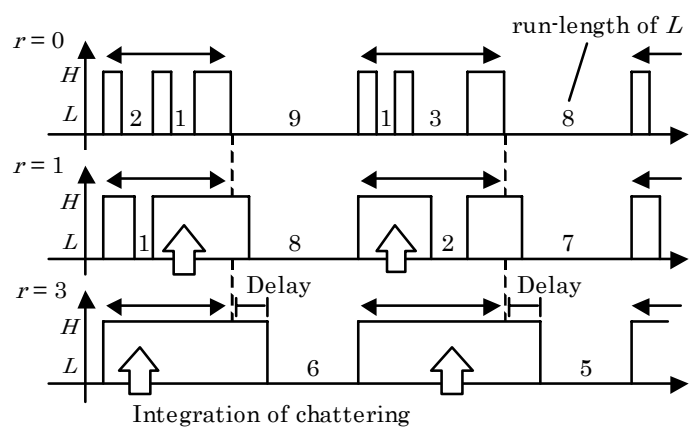

図 6 分断された動作の結合

Fig. 6. Integration of divided motions

を 1 フレーム分だけ移動させ，常に最新フレームの直前の ブロックを利用するようにする。ここで異常検出の際に最 新の 1 ブロックのみを利用することで, 異常状況の発生直 後でも即時にその異常を検出できることが期待できる。

図 4 に本手法の流れを示す。まず，前処理として画像を ブロックに分割し，ブロック内の平均濃度值を算出する。 これにより計算量を軽減させるとともに，ノイズの影響を 最小限に抑える効果が期待できる。そして，ブロック内に おける何らかの動作（物体の移動やランプの点消灯など） を検出するために，前時刻との差分を取り，差分值の 2 值 化を行うことで，ブロック内の変化を検出する。

次に，何らかの動作が検出された場合，それが本手法の 対象とする周期的動作か，それとも周期性を持たないノイ ズかを判別するために，動作の周期性を検出する。ここで, 周期性の検出のために 2 值の投票と各周期における投票の エントロピーの算出を行う。動作に周期性が認められた場 合，その周期性の乱れを監視することになる。

最後に，周期的動作における周期の乱れを検出した場合 に異常とみなし，その異常度の大きさを算出する。そして， 異常度が大きい場合, 異常が発生したとみなし通知を行う。

以下，ブロック列 $(i, j)$ に対する具体的な処理の流れにつ いて説明を行う。

〈3·2〉 2 值ポイントの算出 まず, ブロック内におけ る動作を検出し, 各時刻において動作が発生したブロック に $H ，$ 未発生のブロックに $L$ を対応させる。

最初に, 前処理としてブロック内の平均濃度值 $\mu_{t}$ を算出 する。そして現時刻 $t$ と前時刻 $t-1$ のブロックにおける平均 濃度值の差分 $\delta_{t}$ を算出する。ただし $\delta_{t}$ が実数值を取る場合, 四捨五入して整数值とする。以下， $\delta_{t}$ をポイントと呼ぶ。
表 1 ランレングス平均值の最大化

Table 1. Maximization of averaged run-length values

\begin{tabular}{c|l|c}
\hline \hline$r$ & run-length of $L$ & averaged run-length \\
\hline \hline 1 & $1,8,2,7, \cdots$ & 4.5 \\
\hline 2 & $7,1,6, \cdots$ & 4.7 \\
\hline 3 & $6,5, \cdots$ & 5.5 \\
\hline 4 & $5,4, \cdots$ & 4.5 \\
\hline 5 & $4,3, \cdots$ & 3.5 \\
\hline
\end{tabular}

$$
\delta_{t}(i, j)=\left|\mu_{t}(i, j)-\mu_{t-1}(i, j)\right|
$$

ここで $\delta_{t}$ が大きな值をとる場合, 濃度值の変化が大きく， ブロック内にて何からの変化が発生していると考えること ができる。したがって, ポイント值について適当な閾值 $t h$ を 定め, 2 值化を行うことで, 変化の発生したブロックと未発 生のブロックを区別することができると考えられる。ここ では Fisher の線形判別法を用いて, 閾值 $t h$ を定める。スラ イド空内のブロック $n+1$ 個におけるポイントについて, そ の取りうる值の範囲を $P_{\min }$ から $P_{\max }$ までの整数值, 2 值化の 際 $t h$ 未満となるブロックの平均ポイントを $\bar{P}_{0}$, th 以上とな るブロックの平均を $\bar{P}_{1}$, 全体の平均を $\bar{P}$, ポイント值 $k$ を 持つブロック数を $n_{k}$ とし，

$$
\begin{gathered}
\sigma_{B}^{2}=\frac{\sum_{k=P \min }^{t h-1} n_{k}\left(\bar{P}_{0}-\bar{P}\right)^{2}+\sum_{k=t h}^{P_{\max }} n_{k}(\bar{P}-\bar{P})^{2}}{\sum_{k=P \min }^{P \max } n_{k}} \\
\sigma_{I}{ }^{2}=\frac{\sum_{k=P \min }^{t h-1} n_{k}(k-\bar{P})^{2}+\sum_{k=t h}^{P \max } n_{k}(k-\bar{P})^{2}}{\sum_{k=P \min }^{P \max } n_{k}} .
\end{gathered}
$$

とし， $\sigma_{B}{ }^{2} / \sigma_{I}{ }^{2}$ が最大となるように閾值 $t h$ を定める。ただ し $P_{\max }$ が一定值以下の場合はノイズとみなし, 2 值化を行わ ず全て $L$ とみなす。

しかし，テクスチャを持つ物体の移動時などでは，1回の 動作の途中において大きく $\delta$ が変化する現象が発生する。 図 5(a) に縦軸をポイント值，横軸を時系列としてその様子 を示す。単純に図 5(b) のように 2 值化を行うと $H$ と $L$ が不 規則に変化し 1 つの動作が複数に分断されてしまうことが ある。これはノイズの増加による信頼性の低下につながり 好ましくない。そこで図 5(c)のように一続きの動作をまとめ るために, 以下の方法を用いて 2 值ポイント $B_{t}$ を算出する。

$$
B_{t}(i, j)= \begin{cases}H & \left(\text { if } \max \left(\delta_{t}(i, j), \cdots, \delta_{t-r}(i, j)\right)>t h(i, j)\right) \\ L & \text { (otherwise) }\end{cases}
$$

ここで $\max \left(\delta_{t}, \cdots, \delta_{t-r}\right)$ は, 時刻 $t$ から $t-r$ までのポイント值 の最大值を表す。数フレーム間の最大值を取ることにより, $H$ と $H$ の間に含まれている短時間の $L$ を削除することが できる。例えば, 図 6 に示すようなポイント列を考えると, 単純に 2 值化 $(r=0)$ を行うと動作の分断が生じるが, $r=1$ 


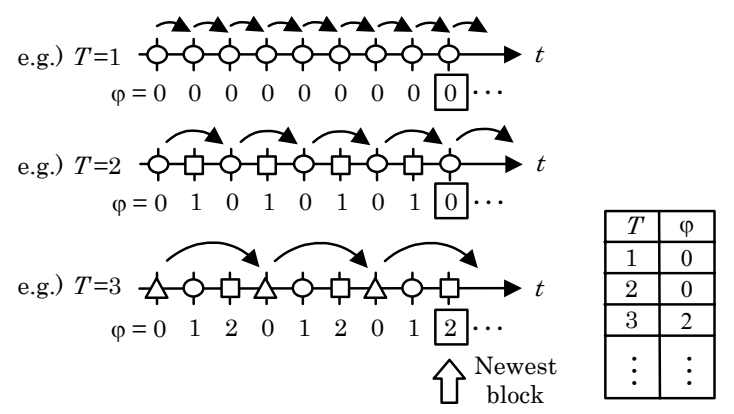

困 7 周期と位相の対応

Fig. 7. Relation between cycle time and phase

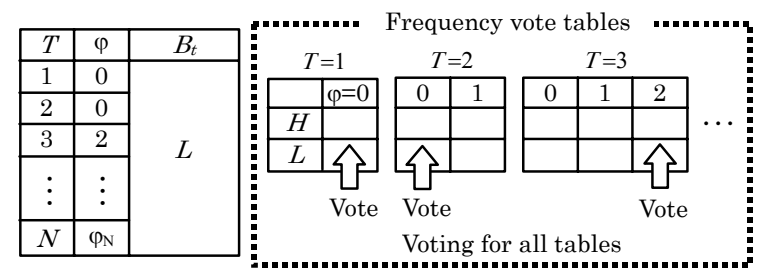

図 8 周波数空閒への投票

Fig. 8. Voting to the frequency vote space

とすることで長さ 1 の $L$ が削除されることが分かる。同様 に $r=3$ とすることで長さ 3 以下の $L$ が削除され, 動作の分 断を回避することができる。ただし $r$ の值が大きくなるにつ れて，処理に若干の遅れが発生するようになる。単純に閾 值 $t h$ を低い值に設定してもこの現象の回避は可能だが，ノ イズの影響を受けやすくなるという問題が発生する。

ここで, 最適な $r$ を求めるために, 図 6 における $L$ の長さ を示すランレングスの平均值を表 1 に示す。 $r$ が過小の場 合, 十分な結合処理が行えず，長さ 1 程度の短い $L$ が残る ことで平均值は小さくなる。逆に $r$ が過大の場合, 全体的に $L$ の長さが小さくので, やはり平均值は小さくなる。した がって, 平均值が最大值を取る $r$ を使用するのが適当である と考えることができる。

〈3・3〉 2 值ポイントの投票 次に, 検出された動作が 本手法の対象とする周期的動作か，それとも周期性を持た ないノイズかを判別するために周期性の検出を行う。周期 性検出のために，2 值ポイント $B_{t}$ について周波数投票空間 に対して投票を行う。ここでは，動作の周期があらかじめ 分からないため，取りうる全周期を仮定して考える。

まず, スライド空内の時刻 $t$ に対応する位相 $\varphi$ を求める。 図 7 に示すように, 周期ごとに位相は異なる。また, 周期 $T$ における $\varphi$ の取りうる值は 0 から $T-1$ までとなり，位相の 種類の数は $T$ 種類となる。時刻 0 において全周期における 位相が 0 であるとすると, 時刻 $t$, 周期 $T$ における位相 $\varphi$ は

$$
\varphi=t \bmod T
$$

となる。ここで mod は除算の余りを表す。

取りうる周期を 1 から $N$ までとすると, 式(5)より各周期 に対応する位相 $\varphi_{1}, \varphi_{2}, \cdots, \varphi_{N}$ が求まる。次に, 投票空間

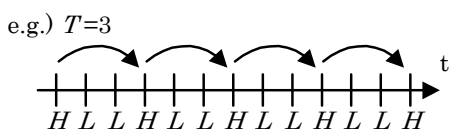

$\varphi=\begin{array}{lllllllllllll}0 & 1 & 2 & 0 & 1 & 2 & 0 & 1 & 2 & 0 & 1 & 2 & 0\end{array}$

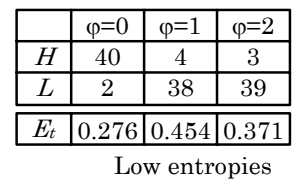

(a) Cyclic pattern and synchronous cycle

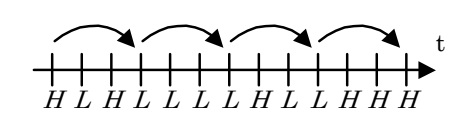

$\varphi=0 \begin{array}{lllllllllllll}0 & 1 & 2 & 0 & 1 & 2 & 0 & 1 & 2 & 0 & 1 & 2 & 0\end{array}$

\begin{tabular}{|c|c|c|c|}
\hline & $\varphi=0$ & $\varphi=1$ & $\varphi=2$ \\
\hline$H$ & 20 & 26 & 21 \\
\hline$L$ & 22 & 16 & 21 \\
\hline \hline$E_{t}$ & 0.998 & 0.959 & 1.000 \\
\hline \multicolumn{4}{|c}{ High entropies }
\end{tabular}

(b) No cyclic pattern

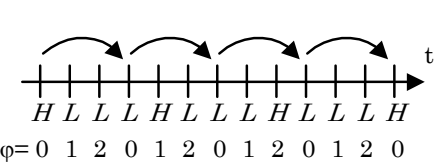

\begin{tabular}{|c|c|c|c|}
\hline & $\varphi=0$ & $\varphi=1$ & $\varphi=2$ \\
\hline$H$ & 20 & 26 & 21 \\
\hline$L$ & 22 & 16 & 21 \\
\hline \hline$E_{t}$ & 0.893 & 0.918 & 0.893 \\
\hline
\end{tabular}

High entropies

(c) Cyclic pattern, but no synchronous cycle

困 9 エントロピーの算出

Fig. 9. Calculation of entropies

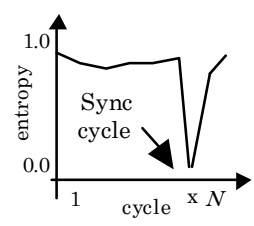

(a) Cyclic motion

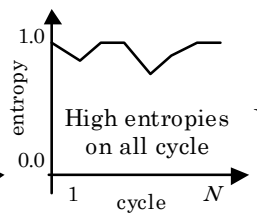

(b) No cyclic motion

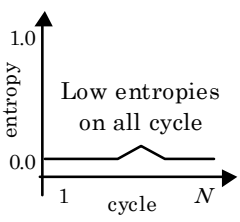

(c) No motion
図 10 周期とエントロピーの関係

Fig. 10. Relations between cycles and entropies

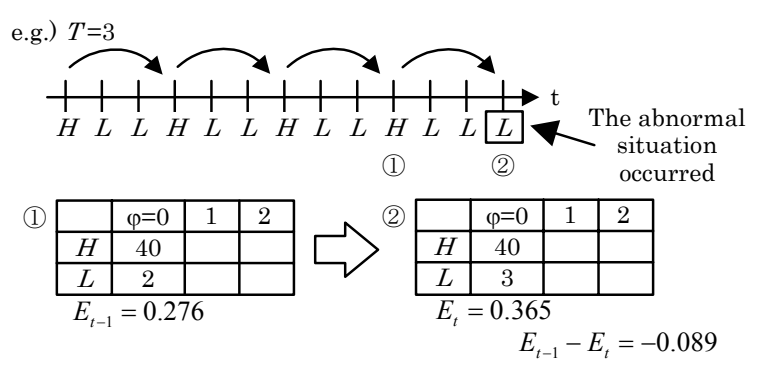

図 11 異常発生時のエントロピーの変化

Fig. 11. Change of entropies on abnormal situation

$(T, \varphi, B)$ において, $\left(1, \varphi_{1}, B_{t}\right),\left(2, \varphi_{2}, B_{t}\right), \cdots,\left(N, \varphi_{N}, B_{t}\right)$ に対 して一票ずつ投票を行う。つまり, 図 8 に示すように, あ らかじめ用意された $N$ 個の投票テーブルに対して $\varphi$ と $B_{t}$ が一致する個所にそれぞれ一票ずつ，合計 $N$ 票を投票する。 この処理をスライド空内の全時刻について行う。

〈3·4〉各周期における投票エントロピーの算出 次 に投票結果を利用して, 各周期における周期性の強さを調 べるために, 各位相における $H / L$ の割合よりエントロピー を算出する。周期 $T$, 位相 $\varphi$ における $H$ の出現確率を $P_{H}$, $L$ の出現確率を $P_{L}$ とすると, エントロピー $E_{t}$ は

$$
E_{t}(T, \varphi)=-P_{H} \log _{2} P_{H}-P_{L} \log _{2} P_{L}
$$

となる。ここで図 9(a) のように周期的動作が存在し, その 


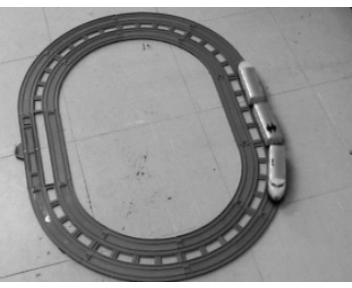

(A) The toy train

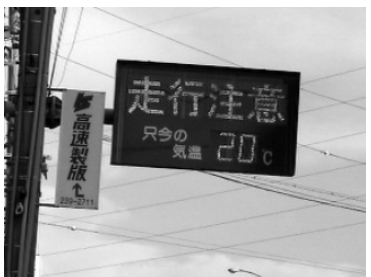

(C) The information board

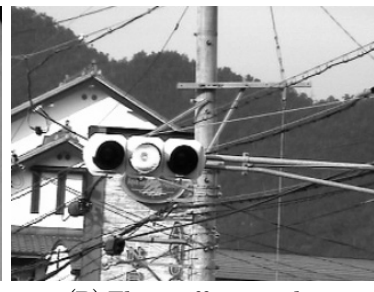

(B) The traffic signal

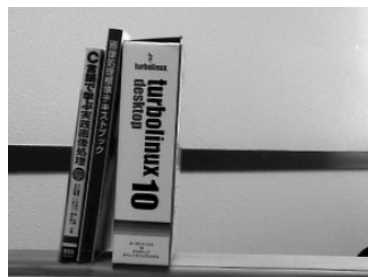

(D) The standing books
図 12 実験用動画像におけるフレームの例

Fig. 12. Examples of frames in experimental scene-images

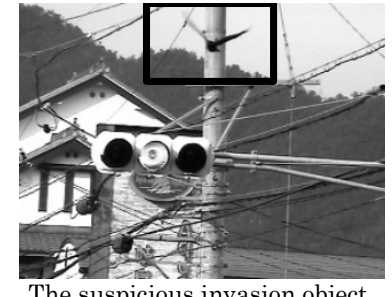

図 13 異常状況の例
Fig. 13. Examples of abnormal situations

周期が $T$ と同期する場合，各位相において $H$ もしくは $L$ が 続けて出現することになり， $E_{t}$ は小さくなる。逆に, 図 9(b) および(c)のように周期的動作が存在しないか周期が同期し ない場合， $H$ や $L$ は不規則に出現することになり $E_{t}$ は大き くなる。つまり $E_{t}$ が小さな值を取る周期 $T$ において，周期 的な動作が存在する可能性が高いと考えることができる。

図 10 に周期と $E_{t}$ の関係を表すグラフを示す。周期的動作 が存在する場合，図 10(a)のように同期する周期の部分のみ エントロピーの值が小さくなる。逆に周期的動作が存在し ない場合, 図 10(b) のように全周期のエントロピーが大き くなる。また, 動作が全く存在しない場合, 全てのブロッ クにおいて $L$ と判断されることから，図 10(c) のように全 周期においてエントロピーが小さくなる。

$\langle 3.5\rangle$ 異常状況の検出 前述に示した方法で動作の 周期性を検出した後，最新フレームにおける周期性の乱れ から，異常状況の検出を行う。運動の周期性が乱れた場合， 図 11 に示すように，エントロピーを増大させる方向に投票 が行われ， $E_{t-1}-E_{t}$ が負の值を取ることになる。ここで $E_{t-1}$ の值が小さいほど周期性が正確であるため，その周期性が 乱れた場合の異常度が大きいと考えることができる。

ここで，異常度に応じた異常ポイント $P_{\text {abnormal }}$ を

$$
P_{\text {abnormal }}=1-E_{t-1}(T, \varphi)^{2}
$$

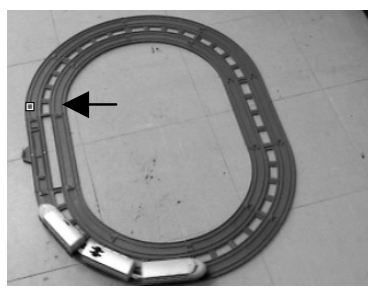

(a) A target block

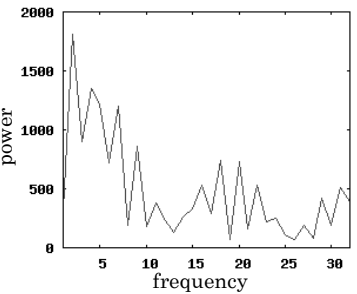

(c) Power spectrum (FFT)

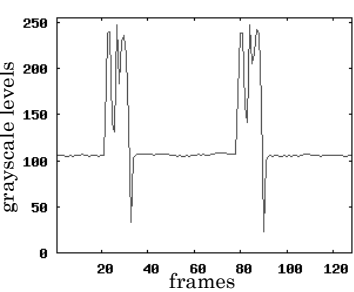

(b) Averaged grayscale levels

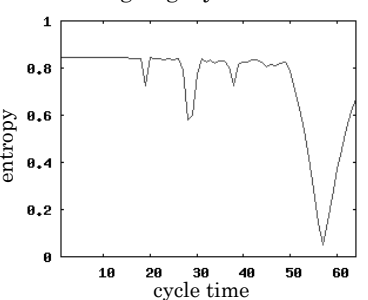

(d) Entropies (proposed method)
図 14 FFT と提案手法による周期性検出結果例

Fig. 14. Examples of detected periodicity using FFT and proposed method

と $E_{t-1}$ の值が小さいほど異常度が大きくなるように定める。 ここで指数を用いることで正常時と異常時の差を大きく し，より正確な異常検出が可能になることが期待できる。 $P_{\text {abnormal }}$ を各周期において算出し, それらの合計值が閾值を 超えた場合に異常が発生したと判断する。今回は, 画面上 の異常個所にブロックを表示することで通知を行う。

\section{4. 実験と考察}

以上に述べた手法を用い，実際に撮影した映像を用い， 異常状況の自動検出を試みた。

〈4-1〉 実験条件 実験には図 12 に示す 4 種類の映像 $(320 \times 240$ pixels， 256 階調グレースケール，10 フレーム ／秒）を用いた。映像中には, 図 13 に示すような異常状況 が発生している。以下に, 各映像の異常状況を示す。

（A）おもちゃの電車（レール上を規則的に走る状態を正常， 電車が突然停止した状態を異常とみなす)

（B）交通信号機（黄信号が点滅寸る状態を正常, 色変化や点 滅の停止，障害物が入ってきたときに異常とみなす)

(C) 電光掲示板 (文字が規則的に点滅する状態が正常, 点滅 が停止したときに異常とみなす)

（D）立てかけてある本 (動かない状態が正常, 本が倒れたと きに異常とみなす）

また，ブロックのサイズを $8 \times 8$ ，周期性の検出に使用す るスライド空の大きさを 300 フレーム, つまり図 3 におい て $n=300$, 想定する周期の範囲を 1 から 64 フレームまで, つまり図 8 において $N=64$ とし，PC（Pentium4-2.8GHz， RAM 512MB, Vine Linux 3.2) により C 言語にて作成さ れたプログラムを用いて処理を行った。

また, 提案手法との比較のため, 従来手法として, FFT を利用した周期性検出を行った。ここでは 16 フレーム経過 ごとに過去 64 フレームのブロック内平均濃度值に対して一 次元 FFT を行い，パワースペクトル（直流成分は除く）の 

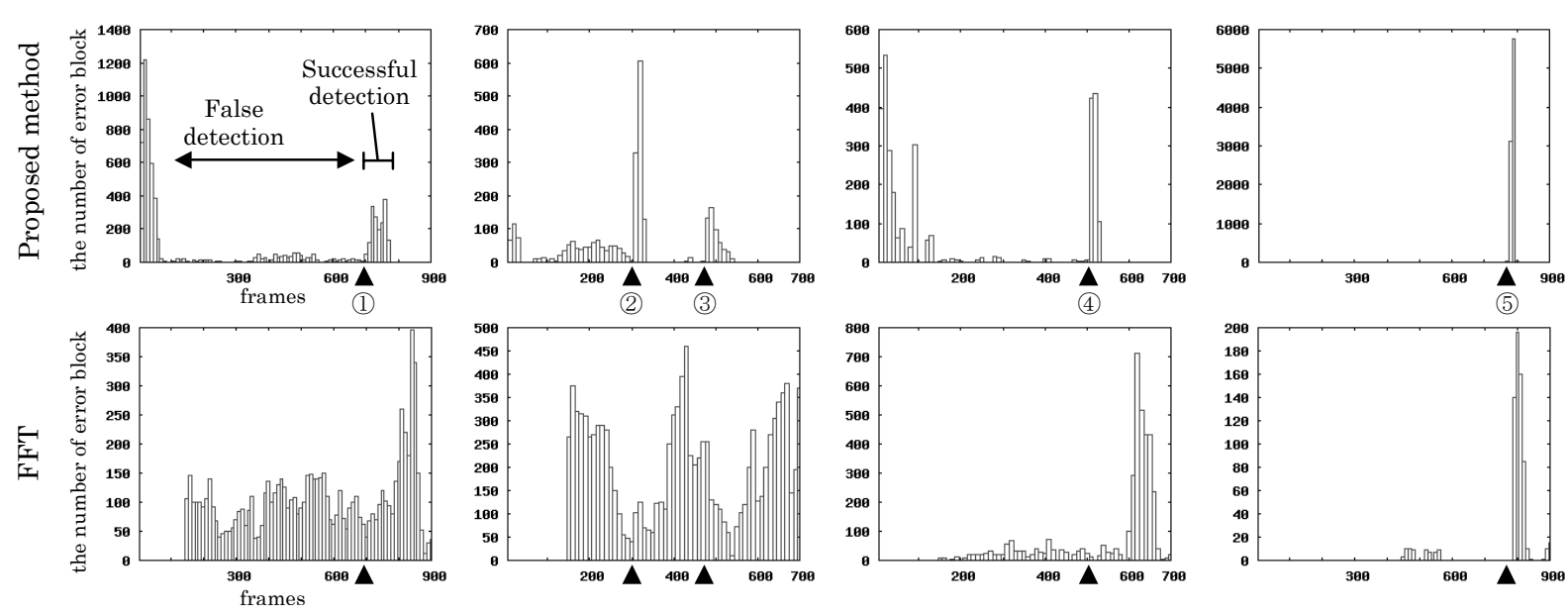

(A) The toy train

(B) The traffic signal

(C) The information board

図 15 異常ブロック数の変化（上：提案手法,下: FFT)

(D) The standing books

Fig. 15. Change of the number of abnormal block (Upper: Proposed method, Lower: FFT)

ピーク位置が 10 以上変化した場合は異常とみなした。た だし，パワースペクトルの最大值が一定值以下の場合，周 期性を検出できなかったとみなし，ピーク位置の検出は行 わないものとした。

$\langle 4 \cdot 2\rangle$ 周期性の検出 まず，周期性の検出に関する 実験を行った。動画像(A)において, 図 14(a) に示す電車の 通過するブロックに着目し処理を行った。図 14(b)のように ブロック内の平均濃度值は電車の形状や影の影響を受け, 大きく乱れた波形となった。平均濃度值に対して FFTを行 った場合, 図 14(c)に示寸パワースペクトルが得られたが, ノイズが多く，本来の運動の周期を判断することは難しい。 それに対して，提案手法では図 14(d)に示すようにエントロ ピーが極端に小さくなる箇所が存在し，本来の運動の周期 が明確に判断できる。以上の結果から，提案手法によって 正しい周期性の検出が可能であることが分かる。

$\langle 4 \cdot 3\rangle$ 異常状況の検出 次に, 提案手法を用いて実 際に異常状況検出を行い, その有効性を検証した。

ここで 10 フレームごとに過去 10 フレーム間に発生した 異常ブロックの総数を図 15 に示す。なお，図のム印は異常 状況（1)：電車の停止，(2)：鳥の侵入，(3)：信号の変化, (4): 電光掲示板の点滅停止, (5) : 本の転倒) が発生した時 刻を表す。図 15 の上段に示した提案手法を用いた実験では, 蓄積されたフレーム数が少ない当初はエントロピーの算出 が不十分であるため，誤認識を起こすことがあったが，100 ～300 フレーム程度蓄積されると誤認識が少なくなること が分かる。また, 異常状況が発生すると即座に異常ブロッ ク数が多くなっており，異常発生を正しくかつ即時に検出 していることが分かる。

一方，図 15 の下段に示した FFT を用いた手法では，異 常状況の発生から異常ブロック数の増加までにタイムラグ が見られ，即座に異常の検出を行うことができなかった。 また，全般的にノイズによる誤認が多く見受けられた。

次に，誤検出数と正検出数の比率を用いた検証を行う。
表 2 FFT と提案手法による誤検出数と正検出数

Table 2. False and successful detection counts using FFT and proposed method

\begin{tabular}{l|c|c|c|c|c|c}
\hline \hline \multirow{2}{*}{ Event } & \multicolumn{3}{|c|}{ FFT } & \multicolumn{3}{c}{ Proposed method } \\
\cline { 2 - 7 } & False & Success & $R$ & False & Success & $R$ \\
\hline \hline (1)Train & 150 & 396 & 2.64 & 59 & 378 & 6.41 \\
\hline (2)Bird & 374 & 460 & 1.23 & 62 & 607 & 9.79 \\
\hline (3) Signal & 374 & 380 & 1.02 & 62 & 163 & 2.63 \\
\hline (4)Board & 70 & 710 & 10.14 & 15 & 434 & 28.93 \\
\hline (5)Books & 10 & 196 & 19.60 & 34 & 5757 & 169.33 \\
\hline
\end{tabular}

有効性に関して数值的に検証する方法として, 全検出数に おける正検出数の割合を正検出率として算出する方法が一 般的に利用されている。しかし, 提案手法では各フレーム においてブロックごとに異常状況かどうかの判断を行って おり, また異常発生前の運動に連動して異常状況の発生を 認識するため, 場所によって異常状況の発生に時間差が生 じるという性質を持つ。そのため, 異常状況が発生したと 判断すべきブロックの位置と数を全検出数として目視によ り数え, 各ブロックに対する正検出率を算出する方法を適 用するのは困難であると考えられる。ここでは, 以下の評 価を用いることで検証を行う。

表 2 に誤検出数と正検出数 (異常の検出数), および誤検 出数と正検出数の比率を用いた評価を示す。ここで誤検出 数は, 図 15 において最初の 150 フレーム経過後から異常発 生までの異常ブロック数の最大值, 正検出数は異常発生後 のフレームにおける異常ブロック数の最大值を表す。

誤検出数と正検出数の比率 $R$ を評価基準として用いるこ とにより，值が高いほど信頼性が高いと判断することがで きる。評価式は以下の式(8)で計算される。

$$
R=N_{s} / N_{f}
$$

ここで， $N_{f}$ は誤検出数， $N_{s}$ は正検出数を表す。 

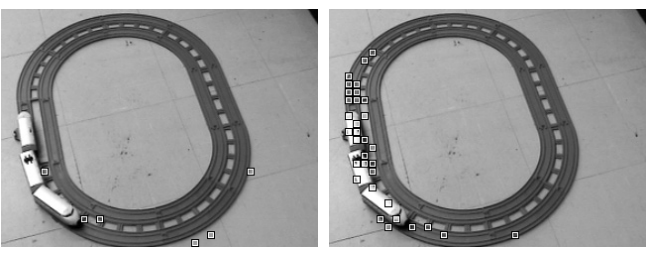

$0.5 \mathrm{sec}$

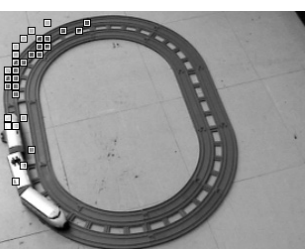

$1.0 \mathrm{sec}$

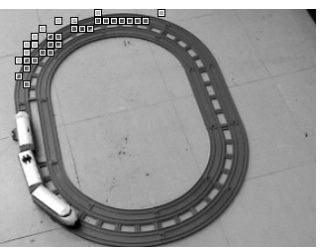

$1.5 \mathrm{sec}$

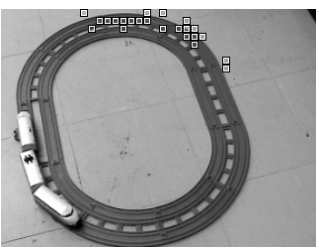

$2.0 \mathrm{sec}$

(A). The toy train (The moving train stopped)

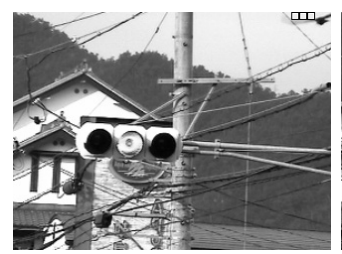

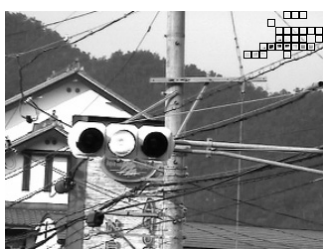

$0.3 \mathrm{sec}$

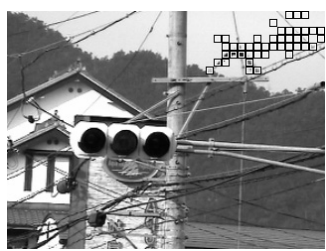

$0.6 \mathrm{sec}$

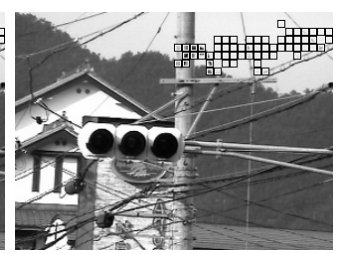

$0.9 \mathrm{sec}$

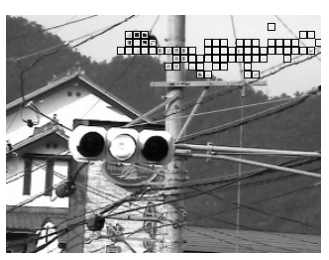

$1.2 \mathrm{sec}$

(B). The traffic signal (The bird came in the scene)

図 16 異常発生直後の異常状況検出結果

Fig. 16. Results of detection just after the abnormal situations occurred

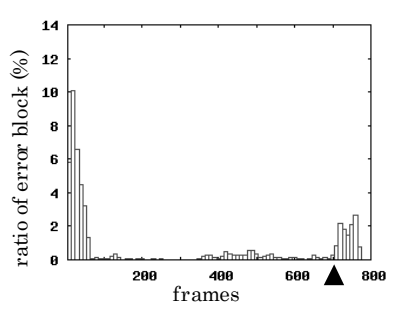

(a) $4 \times 4$

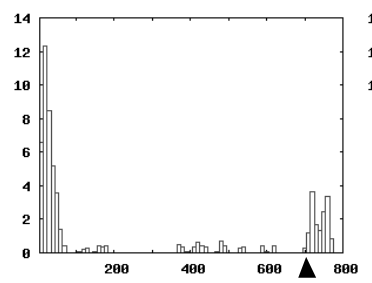

(c) $20 \times 20$

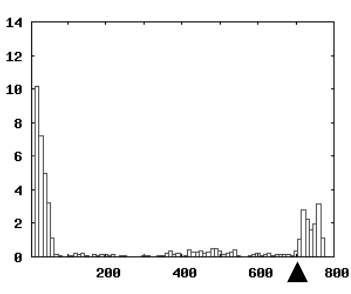

(b) $8 \times 8$

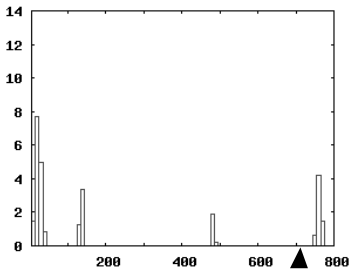

(d) $40 \times 40$
図 17 異なるブロックサイズにおける結果

Fig. 17. Results on different block sizes

提案手法では，誤検出数はいずれのシーンにおいても同 程度であった。正検出数は異常の発生した面積に比例する ため, シーンによってその数が大きく異なることが分かる。 また, 評価值 $R$ は 5 種類の異常状況全てにおいて FFTを用 いた手法よりも高い值が得られた。さらに，両手法ともに 最も $R$ が小さい(3)の状況においては, FFT では誤検出数と 異常検出数の差がほとんど無く, 異常状況の検出が不可能 であったが，提案手法では正検出数が誤検出数の 3 倍近い 值になっており，閾值処理等を用いることで正常時と異常 発生時を区別することが可能であるといえる。

さらに, 図 16 に異常発生直後について詳しく示す。図 16(A)では，それまで周期的に動作していた電車が停止した 場合, 0.5 秒後には異常状況を認識し異常を示すブロックが 大量に発生しており，その後電車の動きに合わせてブロッ
表 3 各処理における処理時間

Table 3. Processing times in each process

\begin{tabular}{|c|c|}
\hline Process & Processing time \\
\hline$\langle 3 \cdot 2\rangle$ Calculation of binaries & $37.1 \mathrm{~ms}$ \\
\hline$\langle 3 \cdot 3\rangle$ Voting & $21.1 \mathrm{~ms}$ \\
\hline$\langle 3 \cdot 4\rangle$ Calculation of entropies & $4.5 \mathrm{~ms}$ \\
\hline$\langle 3.5\rangle$ Detection of abnormal situation & $22.8 \mathrm{~ms}$ \\
\hline Total of all process & $85.5 \mathrm{~ms}$ \\
\hline
\end{tabular}

表 4 異なるブロックサイズにおける誤検出数と正検出数

Table 4. False and successful detection counts on different block sizes

\begin{tabular}{c|c|c|c}
\hline \hline Block size & False & Success & $R$ \\
\hline \hline $4 \times 4$ & 280 & 1261 & 4.50 \\
\hline $8 \times 8$ & 59 & 378 & 6.41 \\
\hline $20 \times 20$ & 18 & 70 & 3.89 \\
\hline $40 \times 40$ & 16 & 20 & 1.25 \\
\hline
\end{tabular}

クが移動していることが分かる。図 16(B)では, 何も動作を していない場所に鳥が侵入した場合, 0.3 秒後には異常を認 識し，その後鳥の動きに合わせてブロックが変化している。 いずれの場合でも即時性の高い異常状況認識が実現できて いることが分かる。

このように，提案手法では同一のアルゴリズムを用いて 移動物体の停止, 周期的な点滅動作の停止, あるいは侵入 物の検出と言った様々な種類の異常状況に対応することが 可能である。例えば, 物体の追跡を行いその動作を解析す ることで移動物体の動作異常を検出したり (4), フレーム間差 分を利用することで侵入者を検出したりする手法(9)なども 提案されているが，提案手法では様々な異常状況に対し， 同一のアルゴリズムを適用できることからより汎用性が高 い異常検出が実現できると言える。 
$\langle 4 \cdot 4\rangle$ 処理時間 以上の実験に対し，各種処理に要 した処理時間について考察を行う。

$\langle 3 \cdot 2\rangle$ 節から〈3.5〉節までの各処理に対する処理時間 をそれぞれ算出したところ, 1 フレームの処理に要する平均 処理時間は表 3 の通りとなった。ここで合計值は $85.5 \mathrm{~ms}$ となり，10フレーム/秒である対象動画像に対して 1 フレ 一ムあたり 0.1 秒以下でその処理が完了できることから, 異 常状況を検出するには実用上十分な速度が得られていると 考えられる。また，〈3.2〉節において閾值を動的に変更さ せる処理の負荷が大きいため, 処理をより効率的に改善で きれば処理時間の短縮が見込まれると考えられる。

〈4·5〉 ブロックサイズに関する考察以上の実験で はブロックサイズを $8 \times 8$ に設定したが, 次にブロックサイ ズを変更させた場合について考察する。

動画像(A)を用いて, $4 \times 4,8 \times 8,20 \times 20,40 \times 40$ の 4 種類のブロックサイズについて同様に実験を行った。その 結果を表 4 に示す。また, 図 17 に縦軸を全ブロック数にお ける異常ブロックの割合としたグラフを示す。今回の実験 では， $R$ が最も優れていた $8 \times 8$ のブロックサイズが適当だ といえる。

ブロックサイズを大きくした場合, 誤検出数・正検出数 ともに少なくなっているが，ノイズにより 1 ブロックが異 常と誤認識した場合，その面積が大きくなるため， $R$ が低 くなり，ノイズの影響が大きくなっていることが分かる。

逆にブロックサイズを小さくした場合, 誤検出数・正検 出数ともに大きくなるが，小さなノイズにも反応すること から，やはりノイズの影響が大きくなっていることが分か る。また, ブロックサイズを極端に小さく設定した場合は, 計算量の増大から処理の遅延の原因になりうるが，今回使 用した PC では， $8 \times 8$ 以上のブロックサイズにおいて 10 フレーム/秒の入力映像に対して, 遅延の発生無しで処理を 行うことが可能であった。

\section{5. まとめ}

周期的に動作する物体の動作を即時に解析し，異常の発 生を即時に検出する方法を提案した。提案手法では, 平均 濃度差分值の 2 值化結果を各周期と位相に応じて投票を行 い，投票の偏りに注目することで周期性を検出する。さら にその周期性を利用し，周期性を乱す入力に対して異常と 判断し, その異常性を検出する。最新フレームに対して常 に異常性を検出することで, 即時的な異常検出を実現する。 異常状況を想定した 4 種類の映像について実験した結果, 異常発生を即時に検出できることを確認した。

今後の課題としては, より多くの動画像のついての検証 や異常ポイントの閾值の自動決定などが挙げられる。

(平成 18 年 5 月 22 日受付, 平成 19 年 2 月 22 日再受付)

$$
\text { 文献 }
$$

(1) J. Yamaguchi, K. Nakazawa, and M. Nakajima : "A Real Time
Intruder Finding System Using Fiber Grating” (in Japanese) 山口順一・中澤和夫・中島真人 :「ファイバグレイティングを用いた 実時間侵入者検知システム」, 電学論 D, 110-D, 7, pp.814-820 (1990)

(2) H. Seki and Y. Hori : "Detection of Abnormal Movement of Industrial Robots Using Image Sequence", Proceedings of The 27th Annual Conference of the IEEE Industrial Electronics Society (IECON'01), pp.1698-1703, Denver (2001)

(3) S. Aoki, Y. Iwai, M. Onishi, A. Kojima, and K. Fukunaga : "Learning and Recognizing Behavioral Patterns Using Position and Posture of Human Body and Its Application to Detection of Irregular State" (in Japanese)

青木茂樹・岩井嘉男・大西正輝・小島篤博・福永邦雄:「人物の位置・ 姿勢に注目した行動パターンの学習・認識と非日常状態検出への応 用」, 信学論 (D-II), J87-D-II, 5, pp.1083-1093 (2004)

(4) S. Kamijo, M. Harada, and M. Sakauchi : "Incident Detection System Combining Statistical Model with Semantic Hierarchy" (in Japanese)

上條俊介・原田将弘・坂内正夫 :「統計モデルと意味階層の結合によ る交通映像異常事象検出システム」, 信学論, J88-A, 2, pp152-163 (2005)

(5) S. Nishino and K. Ohshima : "Fault Detection for IC Board Using Histogram of Thermography" (in Japanese) 西野 聰・大嶋建次 :「赤外線画像のヒストグラムによる IC ボード の故障検出」, 信学論, J82-D-I, 9, pp.1154-1164 (1999)

(6) S. Morita, K. Yamazawa, and N. Yokoya : "Networked Video Surveillance Using Multiple Omnidirectional Cameras", Proc. 2003 IEEE International Symposium on Computational Intelligence in Robotics and Automation, pp.1245-1250 (2003)

(7) J. W.Cooley and J. W.Tukey : "An Algorithm for the Machine Calculation of Complex Fourier Series", Mathematics of Computation, Vol.19, pp.297-301 (1965)

(8) K. Irie and K. Umeda : "Detection of Waving Hands from Images Using Time Series of Intensity Values" (in Japanese) 入江耕太・梅田和昇 :「濃淡值の時系列変化を利用した画像からの手 振りの検出」, 日本ロボット学会誌, 21, 8, pp.923-931 (2003)

(9) H. Yoshikiwa, H. Fujiwara, and S. Kuroda : "Development of Video Surveillance System using Motion Information" (in Japanese)

吉川 寛・藤原秀人・黒田伸一：「動き情報を利用した侵入監視装置 の開発」, 1991 年電子情報通信学会春季全国大会, D-466, pp.7-178 (1991)

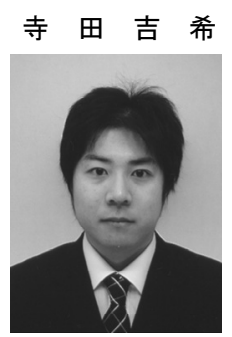

(非会員) 1983 年 8 月 25 日生。 2006 年 3 月 岐皁大学工学部応用情報学科卒業。2006 年 4 月同大学大学院工学研究科応用情報学専攻入 学。現在, 動画像解析の研究に従事。

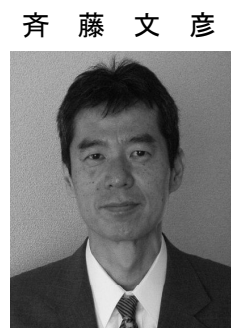

（正員） 1981 年慶大·工・数理卒業。日本 IBM (株) 等を経て, 現在, 岐阜大学工学部応用情 報学科教授。博士 (情報科学, 工学)。視覚情 報処理, 適応型画像処理, 医用画像処理の研究 に従事。1998 年精密工学会小田原賞受賞, 2005 年 IDW’05 Outstanding Poster Paper Award 受賞, 2006 年画像電子学会論文賞受賞。電子 情報通信学会, 日本視鸴学会等会員。 